\title{
Coordination Control and Energy Management of Standalone Hybrid AC/DC Microgrid
}

\author{
Ritu Kandari, Pankaj Gupta and Ashwani Kumar \\ Department of Electronics and Communication Engineering, Indira Gandhi Delhi Technical University for Women, India \\ Corresponding Author: ritu009phd18@igdtuw.ac.in
}

\begin{abstract}
An efficient energy management scheme for a standalone hybrid AC/DC microgrid (HMG) has been proposed in this paper. Energy management in a microgrid is a challenging task, because of the involvement of the distributed energy resources (DERs) which are intermittent in nature. The microgrid may therefore, undergo mismatch in demand and supply, when either the generation or load varies. This mismatch in power may result into DC bus voltage deviations and sometimes these deviations may be out of the permissible limits. A coordination control-based strategy (CCS) for DC bus voltage deviation mitigation and efficient energy management of the standalone microgrid is investigated here. The CCS is tested with the help of simulation studies on a test hybrid AC/DC microgrid in MATLAB covering all the scenarios which may arise. The test microgrid consists of a solar photovoltaic (PV) generation, a secondary source of generation, PEM fuel cell, a battery and a super capacitor. Coordination between the various sub-units and energy management of hybrid AC/DC microgrid is done using Fuzzy Logic Control (FLC) and the DC bus voltage deviations are also compared with PI based control system. It is found that the system with FLC has better performance than PI based control system.
\end{abstract}

Keywords:Energy management; Voltage deviation mitigation; Standalone microgrid; Fuzzy logic control; Hybrid AC/DC microgrid.

\section{INTRODUCTION}

The world is looking forward towards the low carbon footprints and promotion of renewable energy-based generation (Parhizi et al. 2015). With the proliferation of distributed generation (DG), the concept of microgrid has become an interesting topic of research in the last decade. An HMG is composed of an AC bus and a DC bus interconnected using a bidirectional converter. Hence, both AC as well as DC subgrids is there. The limitations of DC subgrid are suppressed by AC subgrid and vice versa are also true. Thus, hybrid microgrid ensures the benefit of the two subgrids in the same architecture (Chenet al., 2017). But there are still open challenges like voltage regulation, frequency regulation in AC subgrid and proper energy management between various subgrids (Kaushik et al., 2014, Planas et al., 2015, Patrao et al., 2015). Since, the renewable energy sources are intermittent in nature, so HESS is also included in the microgrid to support the load during the power mismatch. These storage devices get charged, when the power is in excess, while they get discharged and support the microgrid in case the power is in deficit. HESS are so chosen that one of the component has high energy density, while other has low energy density, so that they may support the system during steady as well as transient state (Choudar et al., 2015, Wang et al., 2019, Ma et al., 2016, Thounthong et al., 2012, Sikkabut et al., 2016). A sudden change in generation or load may cause deviations in the DC bus voltage. Therefore, control strategies are applied for proper management of power and mitigation of bus voltage deviation in a standalone microgrid (Liu et al., 2011, Yazdani et al., 2009). In (Thounthong et al., 2012) super capacitor is used as energy storage device and since supercapacitor has low energy density, it does not perform efficiently during steady state fluctuations. To overcome this, hybrid energy storage device is implemented in (Sikkabut et al., 2016). Many researchers have been working on the power management and voltage control of the HMG during the past decades (Vera et al., 2019, Tummuru et al., 2014, Mishra et al., 2016, Guerrero et al., 2013). 
In this paper a CCS for DC bus voltage deviation mitigation and efficient energy management of a standalone microgrid is proposed. The test hybrid AC/DC microgrid configuration and modeling is further discussed. The proposed coordination control scheme for efficient energy management and DC bus voltage control of the microgrid is investigated. Comparison of PI based and fuzzy based controller is discussed and investigated further in the paper.

\section{MICROGRID CONFIGURATIONAND MODELING}

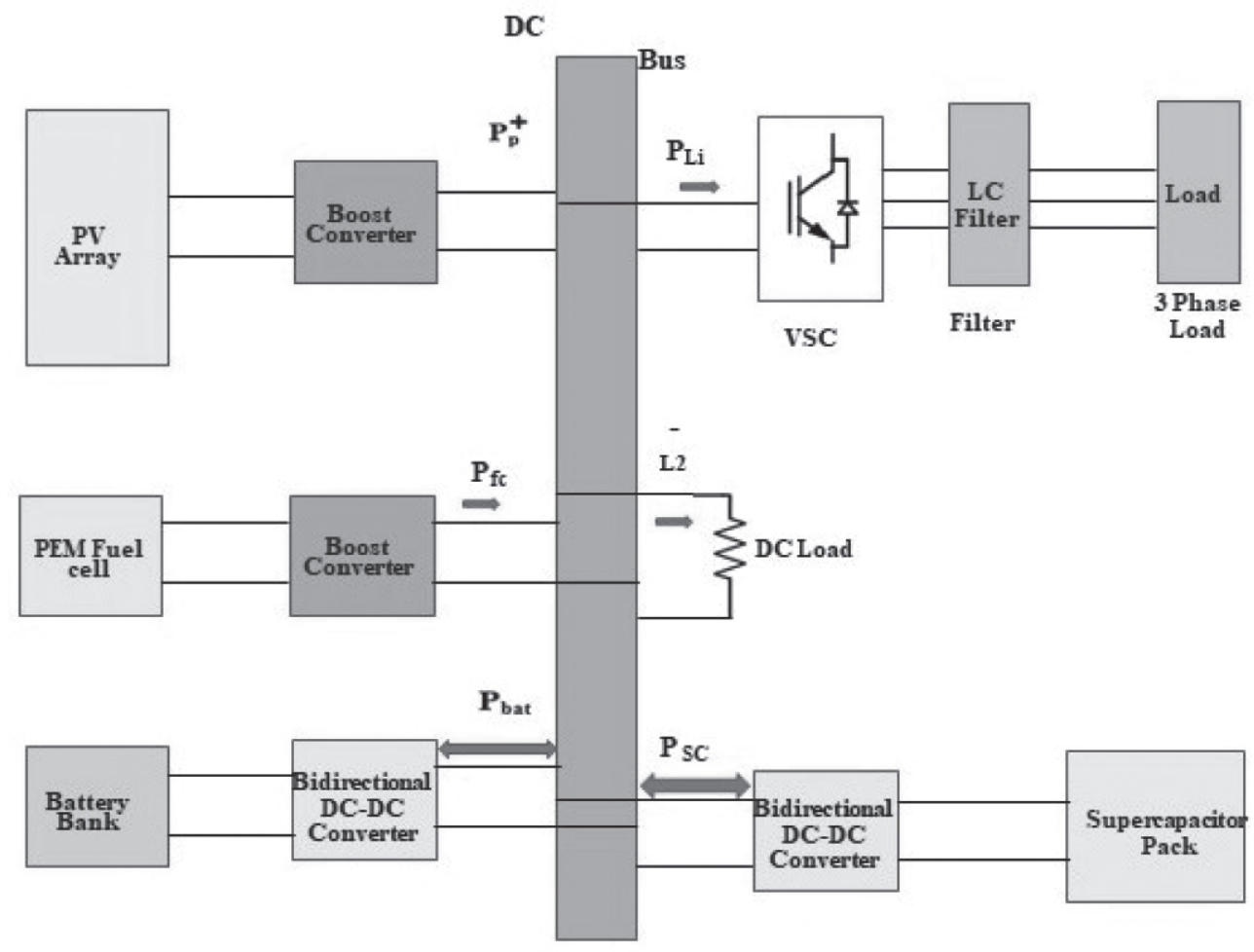

Figure 1. Microgrid Configuration

Figure 1 shows the test standalone HMG, which consists of a PV generation, a fuel cell is used as a secondary source of generation, hybrid energy storage system and a dynamic load.

The PV generation and fuel cell are interfaced with the DC bus through their respective boost converters, which converts the low generated voltage to high bus voltage. The PV array works on maximum power point tracking (MPPT) algorithm using incremental conductance (IC) method for a given value of temperature and irradiance. The hybrid energy storage devices are interfaced with the DC link via their respective bidirectional DC/DC converter. PV source generates steady power to meet the demands of the load, while fuel cell acts, when the power generation by the primary source of supply i.e. PV is not able to serve the load. The battery energy source having high energy density supports steady state power variations in generation and consumption, while the super capacitor supports transient power variations in generation and demand by the loads. The super capacitor has low energy density, so it is unable to support the system during constant power changes. Hence, the hybrid storage system supports the microgrid during steady state as well as transient power variations. 
A solar cell operates as per the following equation

$I_{p v}=I_{p h}-I_{s}\left(\exp \left(\frac{q\left(V_{p v}+I_{p v} R_{s}\right)}{\left(k T_{c} A\right)}\right)-1\right)-\left(V_{p v}+I_{p v} R_{s}\right) / R_{p}$

Where $_{p v}, I_{s}, q, V_{p v}, R_{s}, R_{p}, k, T$ are photovoltaic current, saturation current, elementary charge, voltage of PV, series resistance, parallel resistance, Boltzmann's constant and absolute temperature respectively. The equation of photocurrent shows that the current depends on its temperature and solar irradiation. Fuel cell is used as a secondary source of generation in the proposed system. Power in a fuel cell is produced through electrochemical reaction between hydrogen and oxygen. It does not cause any harmful effect to the environment as it produces water as a byproduct. Hydrogen is used as a fuel and is applied to the anode. This hydrogen is then oxidized to produce electron which can cause electric current to flow in the external circuit (Thounthong et al., 2007, Thounthong et al., 2008). To balance the flow of electrons, the cathode consumes these electrons. Voltage of fuel cells depend upon the voltage of one cell and the number of cells connected. It generates only DC power. A PEM based fuel cell is used in this configuration which is a low temperature fuel cell. It takes less time to start them. A lithium ion battery is used as one of its storage devices to support the system when powers of load and PV are unequal. The working of battery is governed by its state of charge, voltage and current. The mathematical equation for battery energy is as follows

$\mathrm{V}_{\mathrm{b}}=\mathrm{V}_{\mathrm{o}}+\mathrm{R}_{\mathrm{b}} \mathrm{i}_{\mathrm{b}}-\frac{\mathrm{KQ}}{\mathrm{Q}-\int \mathrm{ibdt}}+\mathrm{A} * \exp \left(\mathrm{B} \int \mathrm{ibdt}\right)$

Where $\mathrm{V}_{\mathrm{b}}$ and $\mathrm{i}_{\mathrm{b}}$ are terminal voltage and current, $\mathrm{K}, \mathrm{Q}, \mathrm{A}, \mathrm{B}, \mathrm{R}$ are polarization constant, battery capacity, exponential zone amplitude, time constant inverse and internal resistance respectively.

The second component of hybrid energy storage is a supercapacitor which maintains the dynamic power variations. The super capacitor consists of a capacitor in parallel to a resistance and this combination is further connected to a series resistance. Depending upon the current and voltage rating, super capacitors cells are connected in series and parallel (Tani et al., 2014, Onar et al., 2006).

\section{COORDINATION CONTROLOF MICROGRID}

The test standalone HMG is composed of a PV generation, a fuel cell and HESS as shown in Figure 1. Coordination between these subunits is implemented to mitigate the DC bus voltage deviations and energy management within the system. Hence, converters with controller are connected to them to manage the voltage within permissible limits. Four events are covered in this work to test the proposed control algorithm as shown in Figure 2. Event 1 is the scenario, when load power is more than the generated PV power. Thus, to feed the load, fuel cell, HESS plays the role and maintains the DC bus voltage within permissible limits. During event 2, generation is insufficient to fulfill demand, so fuel cell acting as the secondary source withdraws its power while battery and supercapacitor gets charged by the excess amount of generated power. During event 3, battery SOC is assumed to reach its maximum limit, so it stops charging itself, whereas the supercapacitor helps the system to maintain the DC bus voltage stable during switching transient. During event 4, generated power is made exactly equal to the load power, so, fuel cell and battery remains ideal, while supercapacitor handles during the switching transients. Figure 2 shows the proposed control 


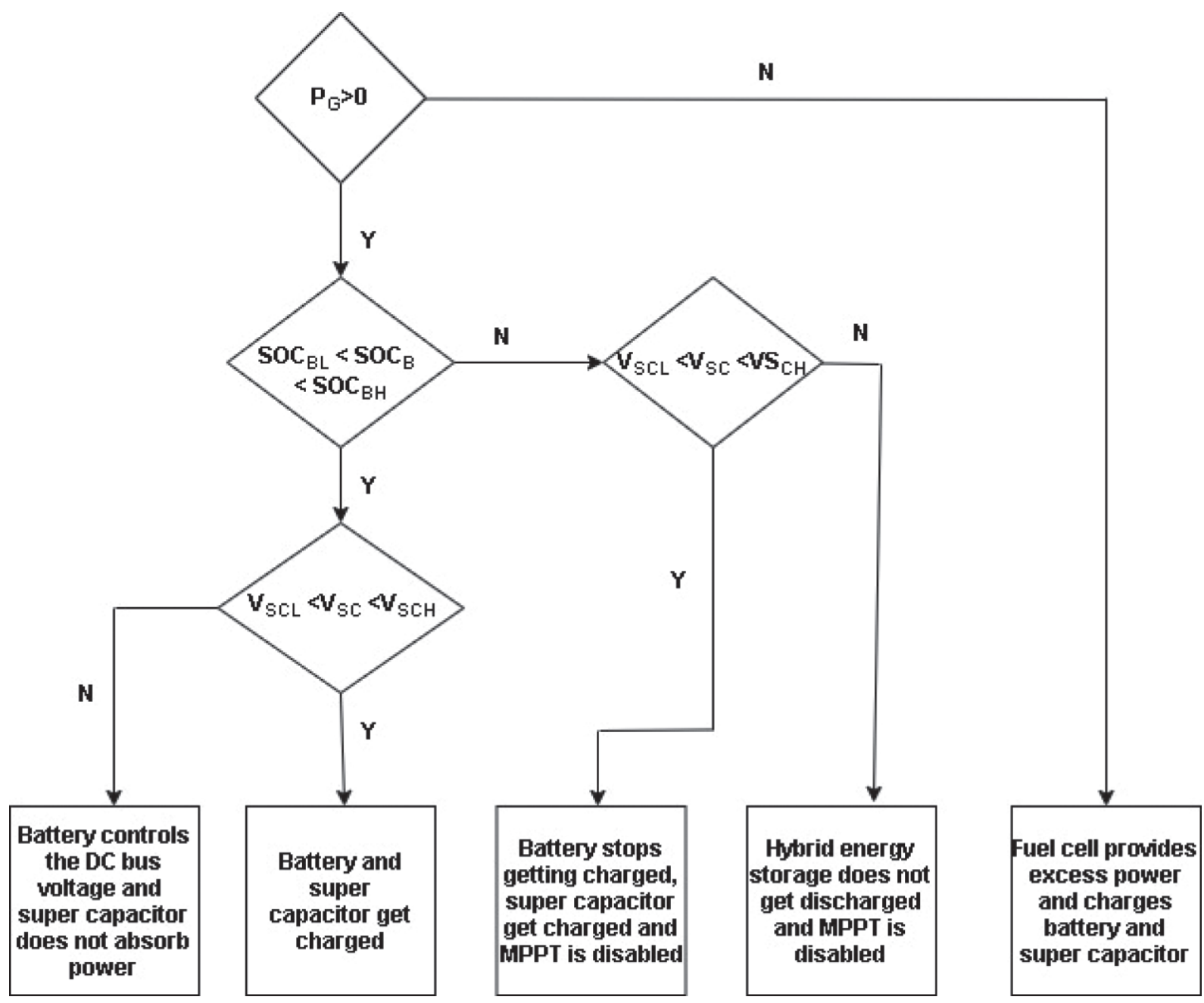

Figure 2. Coordination control strategy

algorithm. First of all, it is checked whether there is any generation by PV, P_G. If there is no generation, then fuel cell provides the required power, while battery and supercapacitor control the DC bus Voltage. If generation is found to be greater than zero, then the SOC of the battery is checked, whether it is within the permissible limits. If the SOC is within the limits then the limits of voltage of supercapacitor is checked. If found within the limits then battery and supercapacitor get charged otherwise only battery controls the DC link voltage, while the supercapacitor stops getting charged. If the SOC is not within the permissible limits, then the voltage of supercapacitor is checked, if it is found in limits, then PV switch off MPPT and only supercapacitor is charged, otherwise both the energy storage devices stops getting charged.

Bidirectional buck boost converter connects the battery to the DC link. When the reference voltage is less than the bus voltage, it charges the battery. For the conditions when the reference voltage is more than the actual DC bus voltage, it discharges the battery to support the load. But the SOC has to be maintained within specified limits. The minimum SOC limit of a battery is $20 \%$, while its maximum limit is $80 \%$. So a bidirectional converter also ensures that battery is not discharged after reaching $20 \%$ of its SOC value. Neither is it allowed to charge above $80 \%$. It first compares the reference voltage with the DC bus voltage; the error is then fed to the fuzzy based controller. The fuzzy controller output is sent to moving average filter to obtain the reference current. This reference current is then compared with the battery current current and is fed to the PI controller to obtain 
pulses for bidirectional DC/DC converter. Battery reference current is subtracted from the total reference current to generate the fluctuating current. This fluctuating current is then fed to PI controller to obtain the reference current for the super capacitor. The error between super capacitor current and its reference currents produces the switching pulses for its bidirectional converter. So the super capacitor absorbs the fluctuating power, when it is in excess and supports the load otherwise. The three-phase dynamic ac load is interfaced with the DC bus via a voltage source converter. This voltage source converter also maintains the DC link voltage, which may change with the varying load conditions. This control scheme consists of two loops technology. Voltage and current loop generate the pulses for voltage source converter. As shown by Figure 3, a fuzzy logic system non-linearly maps the input data into a scalar output data. First of all the input data is converted into a fuzzy set using membership functions. Some set of rules are then applied to make inference. The fuzzy rule matrix used, its surface view and membership functions are represented by Figure 4, Figure 5 and Figure 6 respectively. Then, the fuzzy output is defuzzified using membership function and converted to the scalar output.

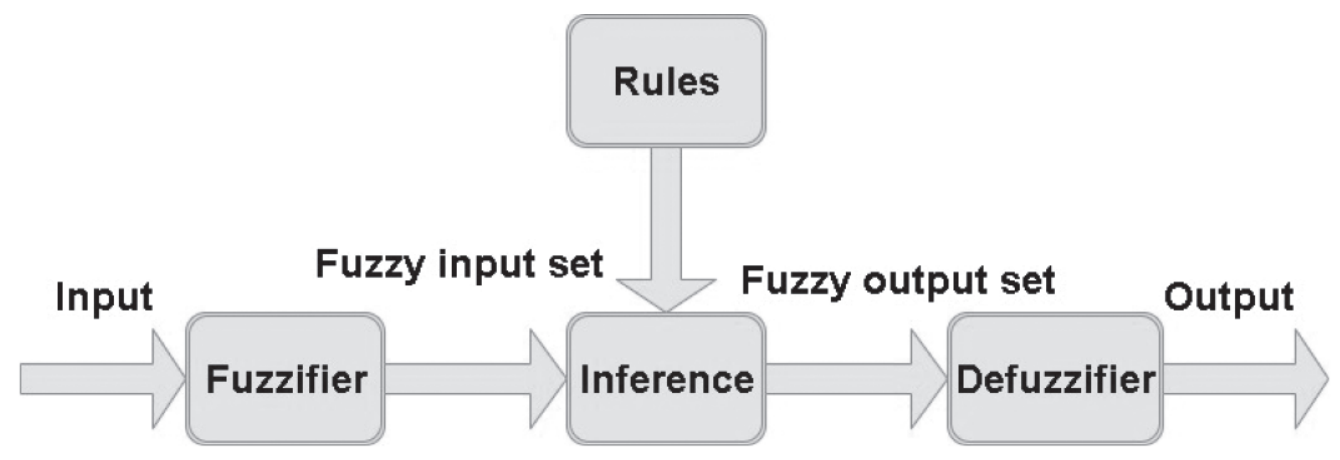

Figure 3. Fuzzy Logic Controller

The output of FLC is fed to voltage regulator. Error signal is given as input to the FLC which is given by

$\mathrm{e}=\mathrm{V}_{\mathrm{DCref}}-\mathrm{V}_{\mathrm{DC}}$

where $\mathrm{e}, \mathrm{V}_{\mathrm{DCref}}$ and $\mathrm{V}_{\mathrm{DC}}$ are error reference DC voltage and DC voltage respectively

Figure 4. Rules for fuzzy logic controller 
And change in error is calculated by subtracting error of $\mathrm{k}^{\text {th }}$ sample and $(\mathrm{k}-1)^{\text {th }}$ sample, which may be expressed as

$\Delta \mathrm{e}=\mathrm{e}(\mathrm{k})-\mathrm{e}(\mathrm{k}-1)$

where $\mathrm{e}(\mathrm{k})$ is the error of $\mathrm{k}^{\mathrm{th}}$ sample, $\mathrm{e}(\mathrm{k}-1)$ is the error of $(\mathrm{k}-1)^{\mathrm{th}}$ sample and $\Delta \mathrm{e}$ is the change in error
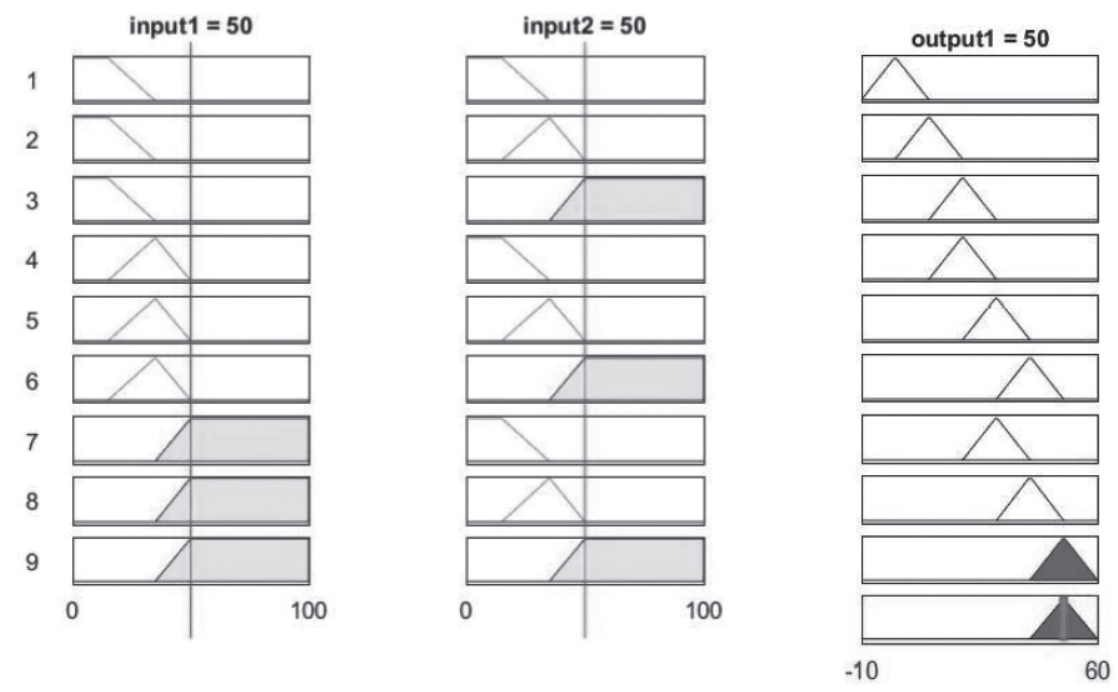

Figure 5. Membership functions for FLC

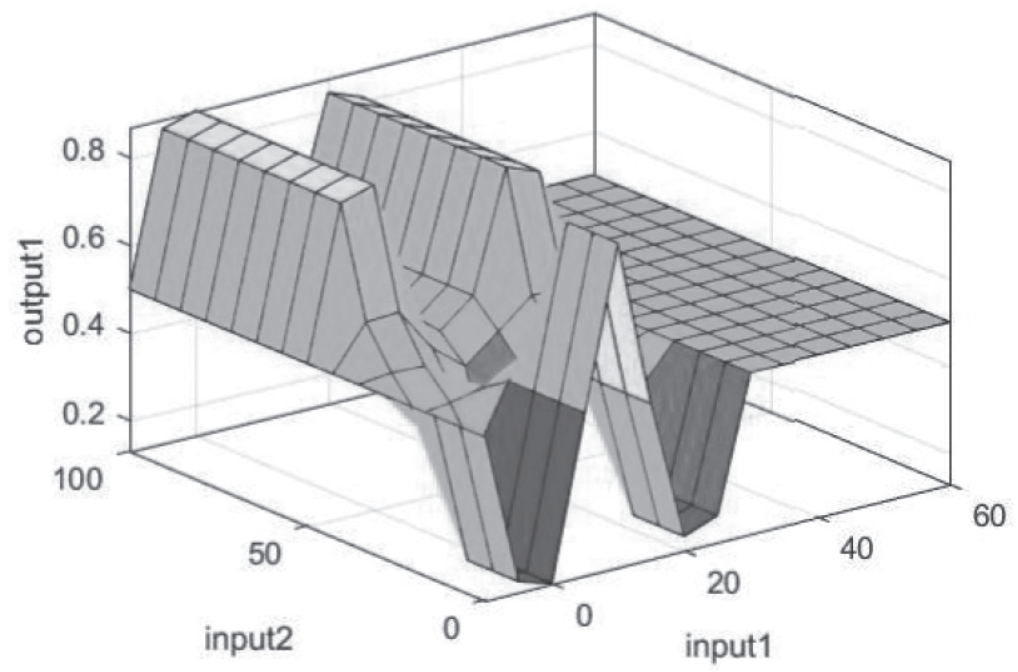

Figure 6. Rules surface view for FLC

Unlike conventional controllers, fuzzy logic control can be treated as an intelligent technique as it works the way human thought process works. PI and fuzzy logic controller are simulated on MATLAB Simulink to minimize the error and mitigate the voltage deviations at the DC bus with the varying load conditions. The output obtained by using FLC is compared with the output obtained with a PI controller. Mamdani design method is used in this paper to make FLC. 


\section{SIMULATION RESULTS AND DISCUSSIONS}

The proposed HMG is modeled and simulated in MATLAB/ Simulink under varying load conditions. Figure 7 and Table 1 shows the coordination control and the corresponding DC bus voltage control in the proposed system. At $\mathrm{t}=0 \mathrm{~s}, \mathrm{PV}$ power is $6 \mathrm{~kW}$ while that required by the load is $8 \mathrm{~kW}$. Hence additional $2 \mathrm{~kW}$ of power is contributed by the fuel cell and the hybrid energy storage devices. During event 1, PV generation is increased, while the load

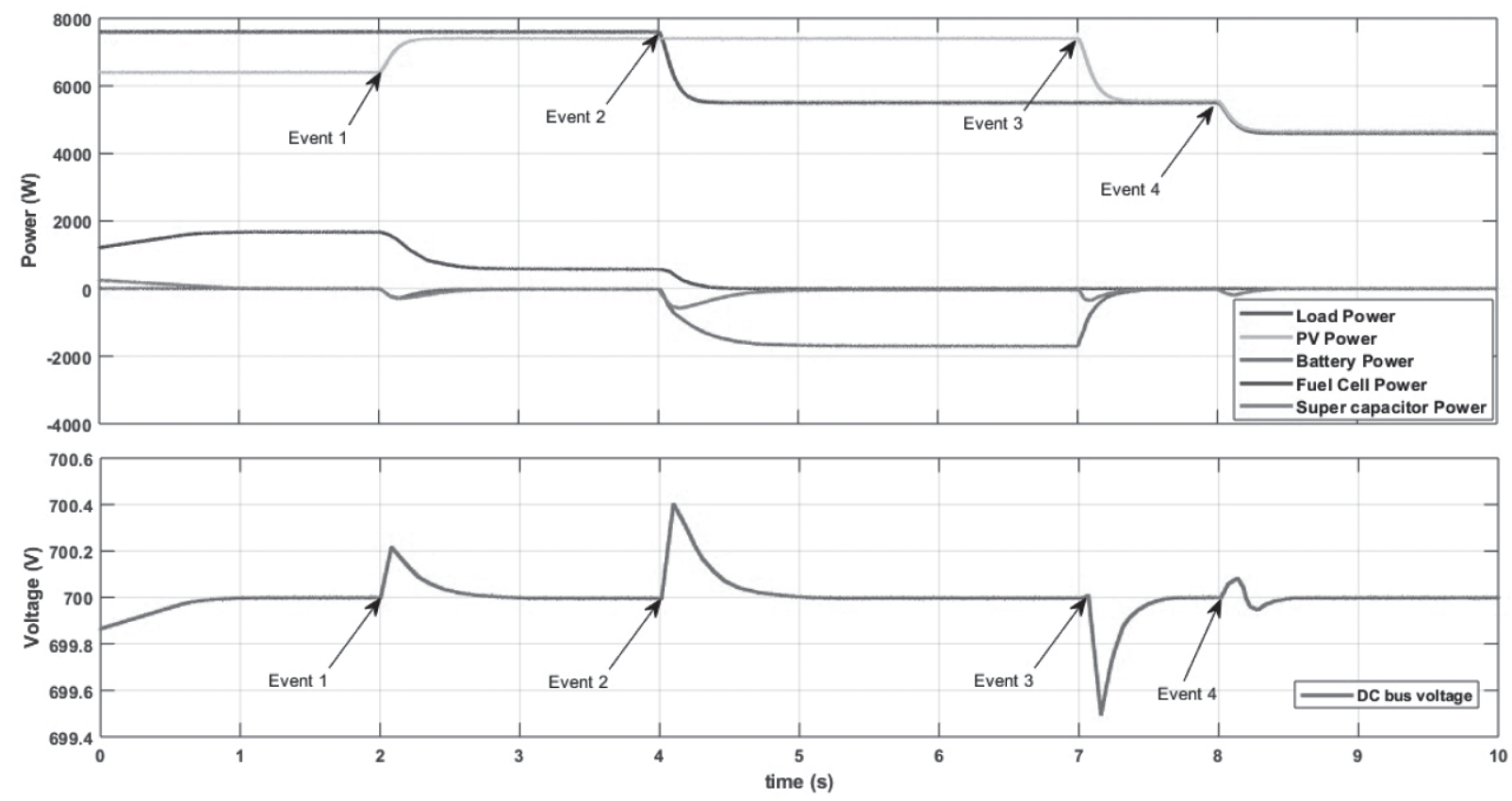

Figure 7. Power variations during various events and corresponding voltage profile with PI control

power is still kept the same, hence fuel cell contribution is reduced. Now, during event 2 , load is reduced to $5 \mathrm{~kW}$, but the PV power is still $8 \mathrm{~kW}$. Hence, the battery starts charging and the fuel cell stops supporting the load, while the supercapacitor comes into role only during the transients. During event 3, the PV generates power sufficient enough to feed the load. Battery and fuel cell reaches to ideal state while supercapacitor comes into action only during the transition and then reaches ideal state. Now, during event 4, PV power and load power both drops to same level, hence making no change in the state of fuel cell and battery. The supercapacitor acts during the transition and maintains the DC link voltage.

Figure 8 shows that initially transients occur, but it takes less time for fuzzy based control to reach its steady state. The PV power is not enough to serve the load. So, this power difference is provided by the secondary source of power generation, fuel cell and the energy 


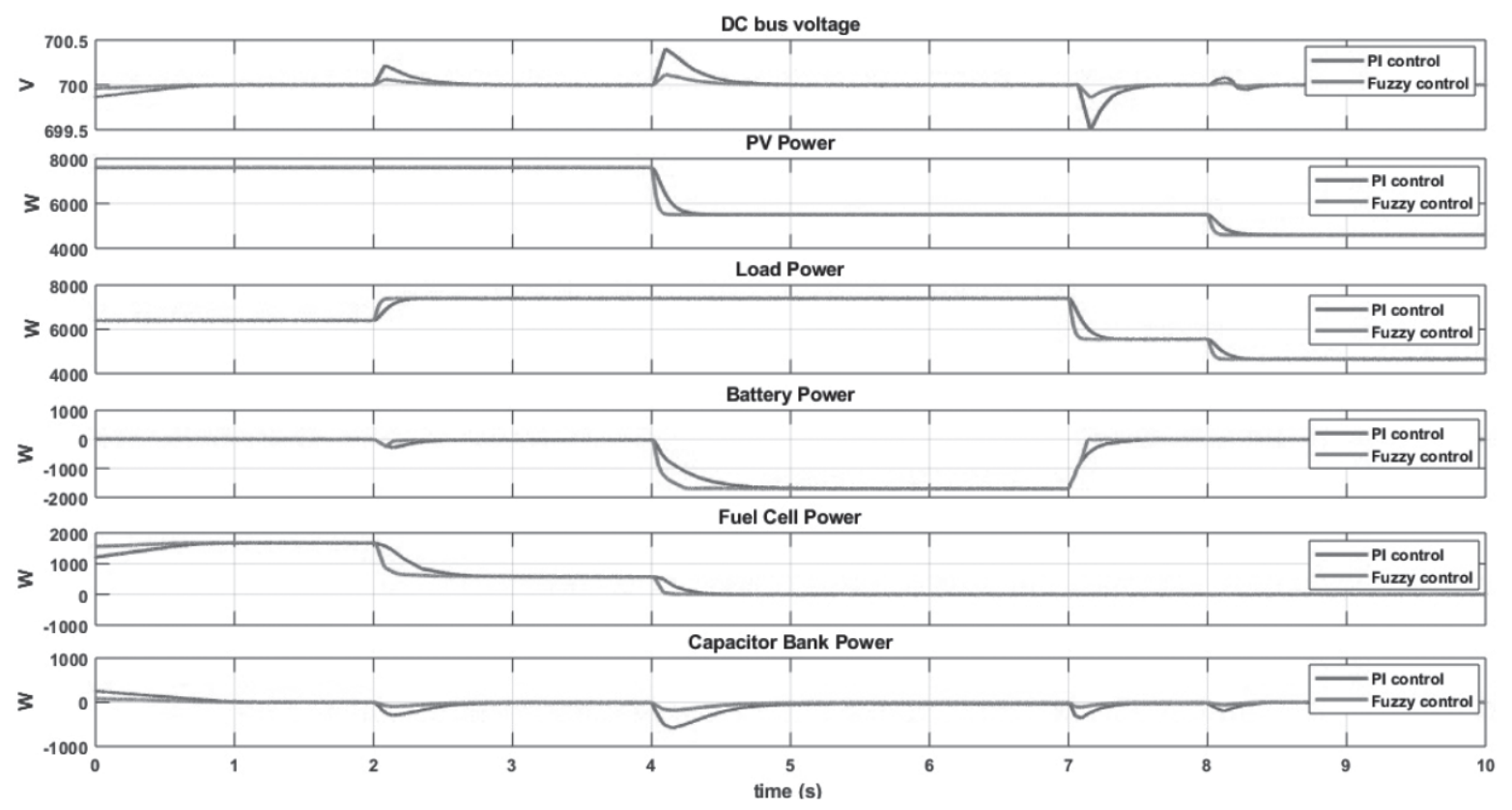

Figure 8. Powers variation of each component during various power mismatch events with $P$ and fuzzy based control

storage devices. In case of PI control based system, the fuel cell takes $0.5 \mathrm{~s}$ in reaching steady state which is reflected by dip in DC bus voltage, whereas in fuzzy control based system, fuel cell starts providing the supply from $\mathrm{t}=0 \mathrm{~s}$ itself so the DC bus voltage is maintained. The supercapacitor supports during this transient period for PI control based system only. At $\mathrm{t}=2 \mathrm{~s}, \mathrm{PV}$ power increases and hence the power supplied by fuel cell decreases. This transition takes $0.1 \mathrm{~s}$ in fuzzy control based system, whereas it takes $0.4 \mathrm{~s}$ to reach its steady state for PI based system. During transients, supercapacitor supports the system to minimize the DC bus voltage deviations. At $t=4 \mathrm{~s}$ the load power decreases and becomes less than that generated by the PV alone. The excess power is utilized in charging the HESS, so that the DC bus voltage remains constant. In fuzzy based system, smooth shift in load is realized and fuel cell stops supplying the load, but it takes $0.1 \mathrm{~s}$ to reach 0 , while PI based system takes $0.3 \mathrm{~s}$ to reach its 0 . At $\mathrm{t}=4 \mathrm{~s}$ the lesser transients are observed for fuzzy based system, so it 


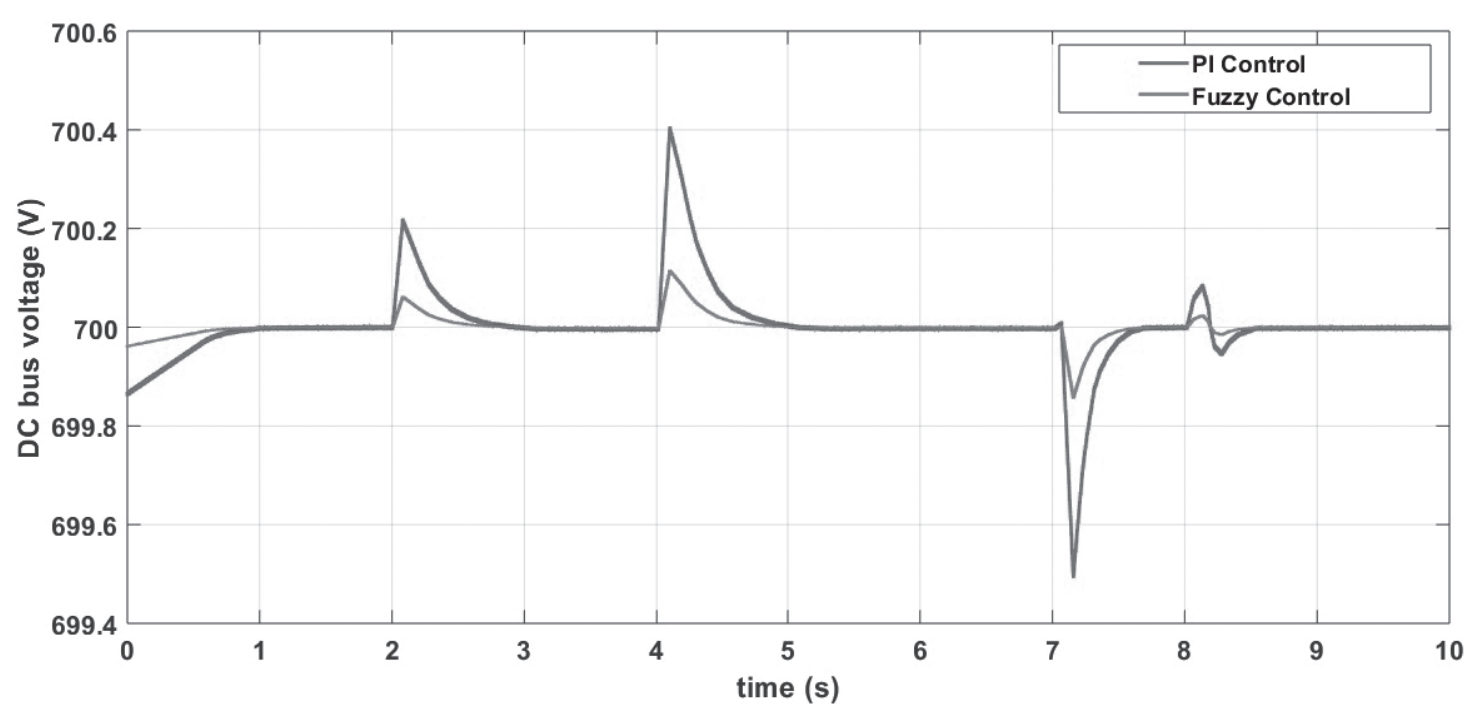

Figure 9. DC bus voltage variations with PI and fuzzy based control

takes lesser power from supercapacitor as compared to PI based system. Now at $t=7$, the SOC reaches its maxima and battery is not allowed to get charged further. So, PV stops working in MPPT mode. At the same instant, the load power also decreases and both the powers become equal. The PV drops its generation within 0.1 s for fuzzy based system, it take $0.3 \mathrm{~s}$ in PI based system. Hence, the supercapacitor takes lesser power for lesser time and maintains the voltage. The DC bus voltage deviation is of $0.1 \mathrm{~V}$ and reaches its steady state in $0.3 \mathrm{~s}$ seconds for fuzzy based system; while it is 0.5 taking $0.5 \mathrm{~s}$ to reach steady state in PI based control. Now, at $\mathrm{t}=8$, the power required by the load further decreases and PV tries to follow the same load power curve. So, at this instant, fuel cell, super capacitor and battery does not need to supply any current to the load, while the PV operates in off MPPT mode. Not much transients are seen, so supercapacitor takes negligible amount of power for fuzzy system and maintains the constant DC voltage while for PI based system, supercapacitor supports for $0.3 \mathrm{~s}$ and maintains the voltage after $0.3 \mathrm{~s}$. After $8.3 \mathrm{~s}$ The PV power is exactly matched with the load power while fuel cell, battery power and supercapacitor remain idle and DC bus voltage is maintained. 
Table 1. Status of all the components of the test Microgrid during all four events

\begin{tabular}{|c|l|l|l|l|l|}
\hline Event & $\begin{array}{l}\text { Status of PV } \\
\text { and load Power }\end{array}$ & $\begin{array}{l}\text { Status } \\
\text { of Battery }\end{array}$ & $\begin{array}{l}\text { Status of } \\
\text { Super- } \\
\text { capacitor }\end{array}$ & $\begin{array}{l}\text { Status of } \\
\text { Fuel Cell }\end{array}$ & $\begin{array}{l}\text { Status of } \\
\text { DC link } \\
\text { voltage }\end{array}$ \\
\hline $\mathbf{1}$ & $\begin{array}{l}\text { PV Power is } \\
\text { increased but it is still } \\
\text { less than load Power }\end{array}$ & Idle & $\begin{array}{l}\text { Absorbs } \\
\text { transients }\end{array}$ & $\begin{array}{l}\text { Contribution } \\
\text { of Fuel cell is } \\
\text { reduced }\end{array}$ & $\begin{array}{l}\text { Peak in } \\
\text { DC link } \\
\text { voltage }\end{array}$ \\
\hline $\mathbf{2}$ & $\begin{array}{l}\text { Load Power } \\
\text { is reduced }\end{array}$ & Charging & Charging & $\begin{array}{l}\text { Fuel cell need } \\
\text { not feed the load }\end{array}$ & $\begin{array}{l}\text { Peak in } \\
\text { DC link } \\
\text { voltage }\end{array}$ \\
\hline $\mathbf{3}$ & $\begin{array}{l}\text { PV Power } \\
\text { is reduced }\end{array}$ & $\begin{array}{l}\text { Charging } \\
\text { is stopped }\end{array}$ & $\begin{array}{l}\text { Absorbs } \\
\text { Transients }\end{array}$ & $\begin{array}{l}\text { Fuel cell need } \\
\text { not feed the load }\end{array}$ & $\begin{array}{l}\text { Dip in } \\
\text { DC link } \\
\text { voltage }\end{array}$ \\
\hline $\mathbf{4}$ & $\begin{array}{l}\text { PV and load } \\
\text { Power are equal }\end{array}$ & Idle & $\begin{array}{l}\text { Absorbs } \\
\text { Transients }\end{array}$ & $\begin{array}{l}\text { Fuel cell need } \\
\text { not feed the load }\end{array}$ & $\begin{array}{l}\text { Peak in } \\
\text { DC link } \\
\text { voltage }\end{array}$ \\
\hline
\end{tabular}

Table 2. DC bus voltage deviations with PI based and fuzzy based control

\begin{tabular}{|c|c|c|c|c|}
\hline S.No. & $\begin{array}{c}\text { Time } \\
\text { (s) }\end{array}$ & $\begin{array}{c}\text { Reference } \\
\text { Voltage(V) }\end{array}$ & $\begin{array}{c}\text { Voltage with } \\
\text { PI control (V) }\end{array}$ & $\begin{array}{c}\text { Voltage with } \\
\text { proposed control (V) }\end{array}$ \\
\hline 1 & 2 & 700 & 700.2 & 700.06 \\
\hline 2 & 4 & 700 & 700.4 & 700.11 \\
\hline 3 & 7 & 700 & 699.5 & 699.86 \\
\hline 4 & 8 & 700 & 700.1 & 700.04 \\
\hline 5 & 8.1 & 700 & 699.9 & 699.99 \\
\hline
\end{tabular}


Figure 9 shows the comparison of DC link voltage for PI controller and fuzzy logic based controller during all the above mentioned events. It is evident from the figure that the deviation of the DC bus voltage from the reference voltage is minimized for fuzzy based control system. Table 2 shows the reference voltage, DC link voltage obtained for PI control based and fuzzy control based system.

\section{CONCLUSION}

A coordination control scheme for efficient energy management of a standalone HMG consisting of multiple energy sources and HESS under varying load conditions is presented in this paper. The coordination between various sub-grids has been efficiently achieved. All possible events of power mismatch have been simulated and successful control of DC bus voltage during these events is done with the help of CCS. The CCS is also implemented using fuzzy control and it has been found that fuzzy based controller performs better in comparison to PI based controller. Power flow between renewable sources, HESS components and load is efficiently managed.

\section{REFERENCES}

SinaParhizi, Hossein Lotfi, Amin Khodaei, and Shay Bahramirad. 2015. State of the art in research on microgrids: A review. IEEE Access, 3:890-925.

Zhenghong Chen, Kangda Wang, Zhengyuan Li, and Tao Zheng. 2017. A review on control strategies of ac/dc micro grid. 2017. IEEE International Conference on Environment and Electrical Engineering and 2017 IEEE Industrial and Commercial Power Systems Europe (EEEIC/I\&CPS Europe), pages 1-6.

Rahul Anand Kaushik and Naran M Pindoriya. 2014. A hybrid ac-dc microgrid: Opportunities \& key issues in implementation. 2014. International Conference on Green Computing Communication and Electrical Engineering (ICGCCEE), pages 1-6

Estefania Planas, Jon Andreu, Jose Ignacio Garate, Inigo Martinez De Alegria, and Edorta Ibarra. 2015. Ac and dc technology in microgrids: A review. Renewable and Sustainable Energy Reviews, 43:726-749.

Ivan Patrao, Emilio Figueres, Gabriel Garcera, and Raul Gonzalez-Medina. 2015. Microgrid architectures for low voltage distributed generation. Renewable and Sustainable Energy Reviews, 43:415-424.

Adel Choudar, Djamel Boukhetala, Said Barkat, and Jean-Michel Brucker. 2015. A local energy management of a hybrid pv-storage based distributed generation for microgrids. Energy Conversion and Management, 90:21-33.

Guizhong Wang, Fengjiang Wu, Hongbo Li, and Yingwei Hou. 2019. Stability analysis and dynamic energy management of pv-hybrid storage based dc microgrid. In Third International Conference on Energy Engineering and Environmental Protection, 227.

Tan Ma, Mehmet Hazar Cintuglu, and Osama A Mohammed. 2016. Control of a hybrid ac/dc microgrid involving energy storage and pulsed loads. IEEE Transactions on Industry Applications, 53(1):567-575.

Phatiphat Thounthong, Arkhom Luksanasakul, Poolsak Koseeyaporn, and Bernard Davat. 2012. Intelligent model-based control of a standalone photovoltaic/fuel cell power plant with supercapacitor energy storage. IEEE Transactions on Sustainable Energy, 4(1):240-249.

Suwat Sikkabut, Pongsiri Mungporn, Chainarin Ekkaravarodome, NicuBizon, Pietro Tricoli, Babak Nahid-Mobarakeh, Serge Pierfederici, Bernard Davat, and Phatiphat Thounthong. 2016. Control of high energy power densities storage devices by li-ion battery and supercapacitor for fuel cell/photovoltaic hybrid power plant for autonomous system applications. IEEE Transactions on Industry Applications, 52 (5):4395-4407. 
Xiong Liu, Peng Wang, and Poh Chiang Loh. 2011. A hybrid ac/dc microgrid and its coordination control. IEEE Transactions on Smart Grid, 2(2):278-286.

Amirnaser Yazdani and Prajna Paramita Dash. 2009. A control methodology and characterization of dynamics for a photovoltaic (pv) system interfaced with a distribution network. IEEE Transactions on Power Delivery, 24(3):1538-1551.

Yimy E.Garcia Vera, Rodolfo Dufo-Lopez, and Jose L. Bernal-Agustin. 2019. Energy management in microgrids with renewable energy sources: A literature review. Applied Sciences, 9(18):3854.

Narsa Reddy Tummuru, Mahesh K Mishra, and S Srinivas. 2014. Dynamic energy management of hybrid energy storage system with high-gain pv converter, IEEE Transactions on Energy Conversion, 30(1): 150-160.

Sukumar Mishra and Rishi Kant Sharma. 2016. Dynamic power management of pv based islanded microgri dusing hybrid energy storage. In 2016 IEEE 6th International Conference on Power Systems (ICPS), pages 1-6.

Tomislav Dragicevic, Josep M. Guerrero, Juan C. Vasquez, and Davor Skrlec. 2013. Supervisory control of an adaptive-droop regulated dc microgrid with battery management capability. IEEE Transactions on Power Electronics, 29(2):695-706.

Phatiphat Thounthong, Stephane Rael, and Bernard Davat. 2007. Control strategy of fuel cell and supercapacitors association for a distributed generation system. IEEE Transactions on Industrial Electronics, 54(6):3225-3233.

Phatiphat Thounthong, Stephane Rael, and Bernard Davat. 2008. Control algorithm of fuel cell and batteries for distributed generation system. IEEE Transactions on Energy Conversion, 23(1):148-155.

Abdallah Tani, Mamadou Bailo Camara, and BrayimaDakyo. 2014. Energy management in the decentralized generation systems based on renewable energy ultracapacitors and battery to compensate the wind/load power fluctuations. IEEE Transactions on Industry Applications, 51(2): 1817-1827.

OC Onar, M Uzunoglu, and MS Alam. 2006. Dynamic modeling, design and simulation of a wind/fuel cell/ultra-ca pacitor-based hybrid power generation system. Journal of Power Sources, 161(1):707-722. 